\title{
Cx9C Motif-Containing Protein 4
}

National Cancer Institute

\section{Source}

National Cancer Institute. CX9C Motif-Containing Protein 4. NCI Thesaurus. Code C84376.

Cx9C motif-containing protein 4 ( $68 \mathrm{aa}, \sim 8 \mathrm{kDa}$ ) is encoded by the human CMC4 gene. This protein plays a role in cellular proliferation. 